\title{
How Does the Arts During the Cold War Reflect the Ideologies of the Two Superpowers?
}

\author{
Lily Wang \\ Whittle School \& Studio Shenzhen Campus, Shenzhen, Guangdong 518066, China \\ *Corresponding Author. Email: lwang1@whittleschool.org
}

\begin{abstract}
The Cold War is a significant point of modern history which put the whole world into tensions and crises; therefore, it resulted in non-eligible influences on people's lifestyles and, thus, caused changes in the expression of art during that time. This paper aims to explore some of the major influences of two main ideologies (communism and capitalism) on artists' choice of topic and techniques in terms of expressing their political position and opinions. In this paper, there are brief analyses of some sample art genres that were popular during the Cold War, like Pop Art, Abstract Expression, Socialist Realism, and Sots Art; overall, they present art's functions and essences in a war of clashing ideology.
\end{abstract}

Keywords: Cold War, Art, Clashing Ideology

\section{INTRODUCTION}

As the Second World War came to an end, the United States rose as a globally dominant power, while Germany, Japan, and Italy fell as vanquished nations and Europe struggled in upheavals and chaos. After WWII, the United States was financially and martially powerful since it was kept away from the devastating war and laid capitalism as the nation's economic and political guideline. The postwar situation benefits the United States by offering them a chance to fiscally support the broke countries through Marshal plans to exert capitalist influence.

Meanwhile, the Soviet Union, one of the significant forces that defeated Nazis and drove them back to East Europe, became the principal rival of the United States. The Soviet Union appealed to many people globally not only because of its sacrifices and contributions during the war but also because of its Communist ideologies that served for the working class's good and called for social justice. Therefore, the Soviet Union was also able to promote its system broadly.

Both the United States and the Soviet Union sought this opportunity to enhance their global influence through constructing its system to a global range. Each believing the other is tyrannical, the two nations quickly divided the world into two blocs with clear segregation of "iron curtain." In order to further propagandize ideologies and cultures, the United States and the Soviet Union incorporated more methods; for example, visual arts were wielded to display ideologies. According to Jessica Gienow-Hecht, all art forms, including paintings, poems, compositions, and films, constitutes part of the culture when their audience receives them. Therefore, the Cold War included artistic or intellectual inspirations to pass on the culture of the two possibilities in defining modernity and state the ideological preconceptions and self-definition to the other nations ${ }^{[1]}$.

In this paper, I will be analyzing some art genres and their sample artworks that could potentially display the severe tension between the two opposite ideologies. While the binary logic permeates into people's lives and cognitions in every regard, artists also adapted it into "a way of seeing" (Curley, 2019) and politicized their works' messages unintentionally ${ }^{[2]}$. For instance, Gerald Laing's Souvenir depicts a quintessential image of the Cold War that avoids the simple division of good or evil. Instead, the work highlights the dissonance of both sides by illustrating President Kennedy and General Secretary Khrushchev as two belligerent and mouthed "monsters." Laing's visual language allows him to remind his audience about a more complicated reality under the candid Cold War rhetoric and emphasizes the aspiration of binary sides to monopolize the world's political system. Similarly, this paper will be digging into the political and social meaning in the art works corresponding to the Cold War's historical and societal background and reality. 


\section{ARTS REGARDING TO AMERICAN's CAPITALISM IDEOLOGY IN THE WEST}

Since the Unites States was one of the binary superpowers, some Western art works blatantly reflect its capitalist, consumerist, and individualist ideologies. Some most well-known art genres based in the Western side are Pop Art and Abstract Expressionism. Artists who performed art works in both of the two genres did reflect, in their art works, about their own interpretation and comprehension to the world's situation and their own society's condition.

\subsection{American Consumerism and Pop Art}

During the Cold War, European and American countries continued their pursuit on Modernism. More than a decade after the end of World War Two, the artists could finally start to confront the roots of the capitalist society's ideologies: materialism, consumerism, militarism, and nationalism. As the major symbol of all these ideologies' combination, the United States became the center of American and British artist's attention of American consumerism; this was the emergence of Pop Art, an art genre that utilized the popular materialism to criticize the hypocrisy of "high art" and the inanity of consumerist culture ${ }^{[3]}$. These Pop Art used everyday imagery, like commercial advertisements and magazine coves to establish provocative gestures.

Sir Eduardo Paolozzi, one of the founders of Pop Art, records daily life under American consumerism. In his early experimental collage series Bunk, Paolozzi consciously analyzes the conditions that he lived in and the images around him to communicate the disseminate methods of American Consumerism culture into people's daily routines and norms. For example, one of the works in the series It's a Psychological Fact Pleasure Helps Your Disposition reflects the ideal life under Capitalism, in which the collage depicts people's lives in houses full of the latest consumer goods and machines. However, the work's details emphasize the two female subjects' isolation to the surrounding world along with the absence of other people's figure. The artist might have intentionally to set the composition in such a fashion to explain how the rise of Capitalism, the heavy reliance on marketing and inert consumer goods, in lives had impaired the inter-relationship between family members. In Paolozzi's work, he alludes at the contradiction of American ideological lifestyle of more consumer goods and a higher life standard of lives might not provide the people with happier, more fulfilled, and content family lives or lifestyle.

Like It's a Psychological Fact Pleasure Helps Your Disposition, other Pop artists reveal their topics from the realist objects in popular culture to question the capitalist society. In Bunkle's opinions:
On the aesthetic level, it [pop art] was hailed as flouting all previous artist tradition, abstract expressionism in particular. Pop art was an iconophile blast at abstract expressionist iconoclasm. On the level of social criticism, pop art has been seen as an iconoclastic blast at consumerist iconophilia, parodying billboard vulgarity, commenting ironically, perhaps satirically, on the consumerist ethnic itself ${ }^{[4]}$.

Pop Art turns attention to the social and political ideologies in the Capitalism during the large influx of American consumer goods and mass media. The artworks reflect the results of the United States' ideologies penetration and propagandas, as well as the artists' skepticism in the influence of the ideologies in living.

\subsection{Postwar Abstraction in Speaking Capitalism}

As a counterpart to Pop Art, Abstraction played a very significant role in the Western Modernism during the postwar period. Some of the Abstraction works indicated the promotion of and hesitation toward the American Capitalism, particularly for the European artists whose countries are invulnerable in front of the Marshall Plan's aids. For example, Alberto Burri, an Italian artist, uses his Abstraction artwork Composition to respond to the post war dilemma in Europe. In Composition, Alberto Burri stitches burlap sacks and gold leaves together; the juxtaposition between the burlaps and gold leaves can symbolize the explicit contrasts between the devastated razed and demolished Europe and the prosperous United States offering them the Marshall Plan. The Marshall Plan would introduce the European countries with American capitals and consumer goods. Burri uses the gold leaf to hint at people's consideration, or even misgivings, toward American capitalist ideology's influxes that might potentially cause blinding consumerism in Europe; essentially, Burri reflects "a set of conditions, a new everyday material landscape, and expressively raged against it, in manifest resistance to Marshall Plan imperialism, disclosing by abstraction the ghosts that haunted the process of European reconstruction ${ }^{[5]}$."

In the United States itself, Abstract Expressionism was developed in the early 1950s, which the name was given afterwards for it's hard to define the art style. Abstract Expressionism was promoting the idea of freedom in expression, where the artists use vigorous and unfussy approaches, action painting, in their artworks. Serge Guilbaut explained to his audience that:

[A]bstract Expressionism was for many the expression of freedom: the freedom to create controversial works of art, the freedom symbolized by action painting, by the unbridled expressionism of artists completely without fetters ${ }^{[6]}$. 
Abstract Expressionism coincided with the American political and cultural movement to the right, which makes the artistic expression a representation of American ideologies toward individualism and liberty; therefore, it is sometimes considered as the promotion to American ideal terms and the bulwark against the communist threats. Paradoxically, Abstract Expressionism, as an avant-garde art form, was also suspected by the conservative critiques, which made the artists getting tired of political establishment. Therefore, Abstract Expression was not a partisan to the American ideologies, but its artist methods and communication tend to exhibit the common features in American ideology propagandas.

\section{THE ARTS of USSR AND COMMUNIST IDEOLOGIES}

After discussing about the Unites States, the next topic to talk about is the other binary force during the Cold War era the Soviet Union. As a totalitarian society, the other side of the iron curtain had a sharp disparity comparing to the beliefs of the US. The Soviet Union believed that people should collaborate to head toward a brighter future; in order to unite everyone in the society, the USSR government monitored the art being created, which leads to completely different art expressions in communist societies.

\subsection{The Soviet Union's Official Art Form- Socialist Realism}

While the European and American artist focused on innovations and renewals in Modernism to fit into the new global context, the Soviet Union reorganized a new pathway. The Soviet Union restricted art into one single official and allowed genre, which is Socialist Realism. Socialist Realism aimed to demonstrate an ideal socialist society, where people appreciate labors, and depict the productive and bright future of the Soviet Union under the regime of Marxist-Leninism. Under the reorganization, Russian artists would have to join Union of Soviet Artist, which recognized Socialist Realism as the only acceptable art form in a socialist society, and the Communist party leaders called for people to abolish "formalism," anything that was not founded on realist and was not socially engaged ${ }^{[7]}$.

In the first Union of Soviet Writers Congress in 1934, the Soviet Union established a clear direction of how Soviet art forms should be like:

Gorky and Andrei Zhdanov attempted to explain the concept of socialist realism and to advance principles such as typicality, optimism, "revolutionary romanticism," "reality in its revolutionary development," as fundamental to the understanding the new doctrine ${ }^{[8]}$.
Therefore, Socialist Realism has to establish a strong sense of optimism about the future industries and manufactures, by using the pictorial composition and construction, to represent the Russian propaganda that proclaims Communism's potential in improving the societal conditions.

With the government's financial and material support, many Socialist Realism works were created to demonstrate Soviet ideologies. For example, Fyodor Shurpin's the Dawn of Our Fatherland depicts a typical example that displays the exuberant and buoyant ideologies about proletarian identity. While mixing landscape and portraits in the same painting, the work wields bright and soft color in the background to demonstrate the rising sun during the dawn; in the middle of the composition, Stalin is looking into the front, which could be interpreted as the future of the Soviet Union's development, with the tractors, factories, and fields behind him. Significantly, the factories and fields symbolize the two main groups of the proletarian identity, which alludes the decisive position of these workers in realizing the sanguine expectations of the future; additionally, Stalin's figure in the middle symbolizes the party leader's position, in a totalitarian society, in directing his people. Also, including "our fatherland" in the title openly suggests that the land is a collective property to all people.

Overall, like the Dawn of Our Fatherland, all the Socialist Realism works have to present the society's reliance on workers and the leader to bring the nation or society into the expected vision of future. Also, it has to show the people's mutual right in owning properties and abolishment in private ownership. These features come together to appreciate labor forces, emphasize leader's heroic figure, and stating people as a whole; these are all subjects supposed to inspire people and awaken their hope to idealistic future, which could guide them to the Soviet Union's ideologies of Communist Collectivism where everyone corporates as worker and laborers in achieving the clear plan for future.

\subsection{Unofficial, Nonconformist, and Underground Arts in the Soviet Union}

While Socialist Realism is adamantly the only accepted art genre in the Soviet Union, the artists were only allowed to make the Socialist utopian prospect, eliminating the freedom to reveal the social issues; therefore, the demand for speaking about the forbidden real social issues in artworks was in eagerness. As a result, artists formed unofficial and underground art committees or groups in private spaces to produce art with prohibited themes, which were not necessarily criticizing the government but instead working as the artists' cathartic expression of subjects they genuinely wanted to discuss. 
This art form that confronted Socialist Realism was unitedly referred as Sots Art, which was a term created by Komar and Melamid in the early 1970s, which came from the Russian for the combination of "Socialist Realism" and "Pop Art". While the Sots artists produced artworks that challenged and questioned the authorities' requirements and rules, they believed that:

Through works in various media and styles, they emphasized the repetitive and kitschy nature of their sources, underscoring the ironic condition of Soviet visual culture. These images and texts had become bankrupt tools of propaganda while remaining part of a shared social language as legible to Soviet audiences as Andy Warhol's soup cans were to U.S. viewers ${ }^{[9]}$.

For example, in Komar and Melamid's work, Stalin and the Muses, the painting is done in a typical Socialist Realist visual style with completely opposite messages in the work. The two artists accentuate Stalin's artificial persona of being "the elevated status that Stalin sought for both himself and for the Soviet Union". Here, they point out the "ideological imperative to legitimate empire" and satirize the media who actively propagated the naïve adoration toward Soviet central power ${ }^{[10]}$. This work represents the topics that Socialist Realist artists would never include in their works; Komar and Melamid use a mocking tone to exemplify the collectivist nature, where the leader is takes a divine position with idealized and dignified figure, in a socialist society.

Another example can be Komar and Melamid's Our Goal is Communism!, a visually simple slogan with Russian writing that says "Our Goal is Communism" and the artists' signature. The slogan was primarily a manifesto of the communist ideologies that propagandized for people's engagement in the system and movement. However, they translated the ideological production into their own style. This translation provokes a conversation between ideology and art which represent the interchangeability nature of ideology.

Sots Art reflected the complex reality of ideology and "create a series of works that lampoon not only the pretensions of Soviet hero-worship, but also those of popular taste and painting itself" [11]. Ultimately, Sots Art present the audience with a new vision of ideologies in the Soviet Union to realize the unspoken sides of propagandas in promoting the ideology. It reflects the Socialist Communist method of shaping the central leader into an authentic figure to meet the totalitarian ideological standards in a sarcastic way.

\section{CONCLUSION}

Since the two superpowers' ideologies molded and shaped the societal conditions during the Cold War, it naturally blended into artists' cogitation and expression in their artistic themes. Whether the artist like or obey the ideologies or not, they would have to express their opinions and questions to the ideologies in the works. On the one hand, art had been utilized as a form of propaganda, in which the artists should explicitly reflect on the ideologies' essences and definitions; on the other hand, art had been connotations and interpretations on the artists' perspectives of the superpowers' manipulations and impacts on the society.

For the artists who live in capitalist societies, analyzing consumerism, materialism, liberty, and individualism would be the themes of their works. They would discuss the consumer goods and capitals in their daily lives and realize the effects of capitalism in changing the lifestyle. For the artists, the government censorship would be a quite important factor in affecting their works; they should either choose to be an authorized artist who creates socialist art works that speaks about the ideal future of Socialism or choose to be nonconformist artists who express the queries and criticism to the government's persona. Artists from both Superpowers' society demonstrated the attributes of the ideologies and commented the gist of the ideologies.

\section{REFERENCES}

[1] Gienow-Hecht, J. (2010). Culture and the Cold War in Europe. In: Leffler, M. P., Westad, O. A. (Eds.), The Cambridge History of the Cold War. Cambridge University Press, Cambridge. pp. 398419

[2] Curley, J. J. (2019). Global Art and the Cold War. Laurence King Publishing, London.

[3] Arnason, H. H. (2010). New Realism and Pop Art. In: Mansfield, E. (Eds.), History of Modern Art: Painting, Sculpture, Architecture, Photography. Pearson Prentice Hall, Upper Saddle River, New Jersey. pp. 501-546.

[4] Kunzle, D. (1984). Pop Art as Consumerist Realism. Studies in Visual Communication. https://repository.upenn.edu/svc/vol10/iss2/3.

[5] Mansoor, J. (2016). Alberto Burri's Plastics and the Political Aesthetics of Opacity. In: Marshall Plan Modernism: Italian Postwar Abstraction and the Beginnings of Autonomia. Duke University Press, Durham. pp. 100

[6] Guilbaut, S. (1984). Conclusion. In: A. Goldhammer (Trans.), How New York Stole the Idea of Modern Art: Abstract Expressionism, Freedom, and the Cold War. The university of Chicago, Chicago. pp. 201.

[7] Bowlt, J. E. (1988). Toward Socialist Realism. In: 
Bowlt, J. E. (Eds.) Russian Art of the Avant-Garde: Theory and Criticism, 1902-1934. essay, Thames \& Hudson, London. pp. 263-297.

[8] Bowlt, J. E. (1988). Toward Socialist Realism. In: Bowlt, J. E. (Eds.) Russian Art of the Avant-Garde: Theory and Criticism, 1902-1934. essay, Thames \& Hudson, London. pp. 290.
[9] Hillings, V. (1999). Komar and Melamid's Dialogue with (Art) History. Art Journal, 58(4): 48-61.

[10] Hillings, V. (1999). Komar and Melamid's Dialogue with (Art) History. Art Journal, 58(4): 50-51.

[11] Hillings, V. (1999). Komar and Melamid's Dialogue with (Art) History. Art Journal, 58(4): 61. 